\title{
PENGARUH MEKANISME GOOD CORPORATE GOVERNANCE, SET KESEMPATAN INVESTASI (IOS) DAN UKURAN PERUSAHAAN TERHADAP KUALITAS LABA
}

\author{
Kurniawati, SE,M.Ak \\ Universitas Bunda Mulia \\ kurniawati@bundamulia.ac.id
}

\begin{abstract}
The quality of earnings reported in the financial statements is one of the key factors to make a decision. This study aims to examine the effect of the mechanism of Good Corporate Governance (GCG), which is proxied by board of commissioner and institutional ownership, the investment opportunity set and the size of the company to the quality of earnings.

The sample used in this researchwere LQ45 companies listed at the Indonesia Stock Exchange during 2012-2015.Samples are collected by purposive sampling and resulted in 15 firms as the final sample. The statistic method used was multiplied analysis linear regression, with hypotheses testing of statistic t tests ( $\alpha$ $=5 \%$ ).
\end{abstract}

The results of this research showed that the institutional ownership has a significant influence to the quality of earnings, while board of commissioner, investment opportunity set and the size of the company has no significant influence to the quality of earnings.

Keywords : good corporate governance, board of commissioner, institutional ownership, investment opportunity set, size of the company, quality of earnings.

\section{Pendahuluan}

Pada umumnya tujuan suatu perusahaan didirikan adalah untuk meningkatkan nilai bagi pemilik perusahaan dan atau para pemegang saham. Untuk mencapai tujuan tersebut salah satu cara yang dapat ditempuh adalah dengan melakukan peningkatan kinerja perusahaan sehingga diperoleh laba yang maksimal. Suatu perusahaan sangat mungkin untuk mendapatkan laba jangka pendek akan tetapi hanya sedikit perusahaan yang dapat terus mempertahankan kelangsungan hidupnya serta mencapai tujuan perusahaan. Untuk dapat mengetahui laba dari suatu perusahaan maka para 
investor, pemilik perusahaan dan pihak - pihak lainya yang berkepentingan dapat membacanya dari laporan keuangan yang diterbitkan oleh suatu perusahaan.

Laporan keuangan merupakan salah satu sumber informasi keuangan yang diberikan oleh perusahaan kepada publik terutama para investor dan kreditor. Salah satu unsur dalam laporan keuangan yang paling banyak diperhatikan informasinya adalah laporan laba rugi. Laporan laba rugi merupakan suatu laporan yang memberikan informasi mengenai laba (earnings) yang mencerminkan aktivitas operasi perusahaan dalam suatu periode. Laba yang berhasil dicapai oleh suatu perusahaan merupakan salah satu ukuran kinerja dan menjadi pertimbangan oleh para stakeholdersmaupun

shareholdersdalam pengambilan keputusan untuk melakukan investasi atau untuk memberikan tambahan kredit.

Kualitas laba dalam laporan keuangan perusahaan penting untuk diperhatikan karena jika kualitas labanya rendah, artinya laba yang dilaporan tidak sesuai dengan kinerja perusahaan yang sesungguhnya, maka hal ini dapat menyesatkan para pengambil keputusan. Kualitas laba yang rendah dapat disebabkan oleh beberapa faktor diantaranya adalah kurangnya pengetahuan dan keahlian pembuat laporan keuangan untuk menyusun laporan keuangan sesuai dengan standar akuntansi keuangan yang berlaku di Indonesia. Jika hal ini terjadi, biasanya tidak menimbulkan akibat yang fatal karena umumnya kesalahan kesalahan penyusunan laporan keuangan dapat ditangkap oleh auditor eksternal untuk perusahaan perusahaan publik. Selain kurangnya pengetahuan dan keahlian, penyebab lainnya yang dapat berakibat fatal adalah adanya unsur kesengajaan dalam melakukan manipulasi laporan keuangan atau melakukan manajemen laba dengan tujuan negatif atau pihak - pihak tertentu saja. Adapun yang menjadi alasan terjadinya kecurangan ini adalah adanya agency problem yaitu karena perbedaan kepentingan antara pemilik perusahaan atau pemegang saham (principal) dengan manager (agent). Pemilik perusahaan atau 
pemegang saham akan memberikan reward,salah satunya berupa bonus bagi pencapaian tujuan perusahaan tersebut kepada si pengelola perusahaan (agent). Dalam rangka memenuhi tuntutan dari pihak para pemegang saham (principal),para manajer (agent) dapat saja terobsesi untuk menunjukkan pencapaian laba perusahaan setinggi-tingginya, padahal kenyataannya tidaklah demikian.

Tindakan _ tindakan yang menyebabkan terjadinya kualitas laba yang rendah dimungkinkan terjadi karena tata kelola perusahaan yang tidak baik, seperti yang terjadi pada bebarapa kasus skandal kecurangan laporan keuangan di beberapa perusahaan besar dunia seperti Enron, WorldCom, Xerox, Tyco dan masih banyak lagi.

Organisation for Economic Cooperation and Development $(O E C D)$ adalah organisasi yang melakukan penyempurnaan atas Good Corporate Governance dengan mengeluarkan Principal of Corporate Governance pada tahun 2004 yang menambah info penting bahwa perlunya penegasan bagi pihak-pihak yang bersangkutan seperti perusahaan, pemegang saham, dan pihak lain untuk melaksanakan Good Corporate Governance secara efektif. Penerapan Good Corporate Governance sangatlah penting karena dapat menjadi solusi untuk meminimalkan agency problem dan kualitas laba yang rendah.Banyak yang memberikan definisi atau pengertian tentang Good Corporate Governance dari berbagai kalangan, salah satunya menurutThe Indonesian Institute for Corporate Governance (IICG)bahwa konsep Corporate Governanceadalahsebagai serangkaian mekanisme untuk mengarahkan dan mengendalikan suatu perusahaan agar operasional perusahaan berjalan sesuai dengan harapan para pemangku kepentingan (stakeholders). Mekanisme Corporate Governance merupakan suatu mekanisme berdasarkan pada aturan main, prosedur dan hubungan yang jelas antara pihak-pihak yang ada dalam suatu perusahaan untuk menjalankan peran dan tugasnya. Lebih lanjut IICG mendefinisikan pengertian mengenai Corporate 
Governance yang baik sebagai struktur, sistem, dan proses yang digunakan oleh organ-organ dalam suatu perusahaan sebagai upaya untuk memberikan nilai tambah perusahaan secara berkesinambungan dalam jangka panjang (www.iicg.go.id).

Penelitian tentang kualitas laba telah banyak dilakukan oleh para peneliti sebelumnya, diantaranya adalah penelitian yang dilakukanoleh Rupilu (2011) yang bertujuan untuk mengetahui pengaruh mekanisme Corporate Governance terhadap kualitas laba dan nilai perusahaan. Mekanisme Corporate Governance diukur dengan menggunakan 4 variabel yaitu komisaris independen, kepemilikan manajerial, kepemilikan institusional dan komite audit atas perusahaan manufaktur di BEI periode 2006-2010. Kualitas laba diukur dengan akrual discretional dan nilai perusahaan dalam penelitian ini diukur dengan nilai Tobin's Q. Hasil penelitiannya menunjukan bahwakepemilikan manajerial, kepemilikan institusional dan komite audit berpengaruh positif terhadap kualitas laba dan nilai perusahaan sedangkan komisaris independen tidak berpengaruh pada kualitas laba dan nilai perusahaan. Selain itu penelitian lainnya tentang kualitas laba juga dilakukan oleh Yushita et al (2013) yang menguji pengaruh mekanisme Corporate Governance,yang diproksikan dengan struktur dewan direksi, kepemilikan manajerial, kepemilikan institusional,komite audit, komisaris independen, kualitas audit eksternal dan likuiditas terhadap kualitas laba. Penelitan ini menggunakan sampel sebanyak 22 perusahaan manufaktur yang terdaftar di BEI pada periode 2007-2011. Hasil penelitian menunjukkan bahwa struktur dewan direksi, komisaris independen berpengaruh positif dan signifikan terhadap Discretionary Accrual atau berpengaruh negatif terhadap kualitas laba dan kualitas audit eksternal berpengaruh negatif signifikan terhadap Discretionary Accrual atau berpengaruh positif terhadap kualitas laba. Sedangkan kepemilikan manajerial, kepemilikan institusional, komite audit dan likuiditas tidak berpengaruh signifikan terhadap kualitas laba. 
Dari uraian diatas, terlihat bahwa kualitas laba yang dilaporkan merupakan hal yang sangat penting dan masih terdapat perbedaan di hasil penelitian. Melalui penelitian ini penulis melakukan penelitian kembali atas topik yang sama dengan perbedaan di periode pengamatan, sampel penelitian serta beberapa variabel penelitian dan pengukurannya.

\section{Tinjauan Pustaka}

\subsection{Stewardship\&Agency Theory}

Stewardship \& Agency theory merupakan dua teori utama yang terkait dengan konsep Corporate Governance (Daniri, 2014). Stewardship theory dibangun diatas asumsi filosofis mengenai sifat manusia yaitu pada hakekatnya manusia dapat di percaya,mampu bertindak dengan penuh tanggung jawab,memiliki integritas dan kejujuran terhadap pihak lain. Dengan kata lain, stewardship theory memandang manajemen sebagai sesuatu yang dapat dipercaya untuk bertindak dengan sebaik-baiknya bagi kepentingan publik pada umumnya maupun pemegang saham pada khususnya. Hal ini bertentangan dengan agency theory yang dikemukakan oleh Jensen \& Meckling (1976) dimana agency theory memandang bahwa manajemen tidak dapat dipercaya untuk bertindak dengan sebaikbaiknya bagi kepentingan publik pada umumnya maupun pemegang saham pada khususnya. Konflik kepentingan (agent conflict) antara principal dan agent akan menyebabkan timbulnya agency cost. Diharapkan dengan dikeluarkannya agency cost dapat mengurangi kerugian yang dapat ditimbulkan (Jensen and Meckling (1976) dalam Daniri (2014)).

\subsection{Mekanisme Good Corporate}

\section{Governance}

Menurut Daniri (2014) Good

\section{Corporate}

Governancemerupakansuatu struktur dan mekanisme yang mengatur pola hubungan harmonis tentang peran dewan komisaris, dewan direksi, rapat umum pemegang saham dan para stakeholders lainnya, mengatur perimbangan kewenangan atas pengendalian perusahaan yang dapat membatasi munculnya dua peluang: pengelolaan yang salah dan 
penyalahgunaan aset perusahaan serta menciptakan suatu proses yang transparan atas penentuan tujuan perusahaan, pencapaian dan pengukuran kinerjanya. Menurut Ahmad Syakhroza dalam Majalah Usahawan edisi Juni (2003), Corporate Governance terdiri dari 6 (enam) elemen yaitu fokus pada board, hukum dan peraturan sebagai alat untuk mengarahkan dan mengendalikan, pengelolaan sumber daya organisasi secara efisien, efektif, ekonomis dan produktif E3P, transparant, accountable, responsible, independent dan fairness - Tarif, tujuan organisasi, strategic control. Keenam elemen ini harus berpadu agar tercipta suatu tata kelola perusahaan yang baik. Berikut ini gambar tentang overviewCorporate Governance dalam perusahaan menurutAhmad Syakhroza dalam Majalah Usahawan edisi Juni (2003)

Gambar 2.1

Overview Corporate Governance dalam Perusahaan

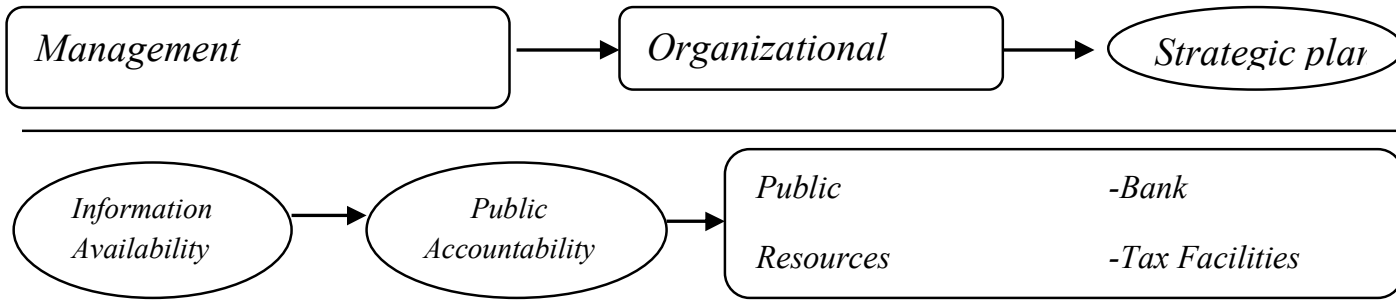

\begin{tabular}{|c|c|c|}
\hline INPUT & PROCESS & OUTPUT \\
\hline $\begin{array}{l}\text { 1. Board Governance } \\
\text { - Characteristics } \\
\text { - Composition } \\
\text { - Structure } \\
\text { - Process } \\
\text { 2. Strategic Planning } \\
\text { 3. Resources }\end{array}$ & $\begin{array}{l}\frac{1 . \text { Board }}{\text { - Best practice of }} \\
\text { Corporate } \\
\text { Governance } \\
\text { - Code of Conduct } \\
\text { 2. Standard Operating } \\
\text { Procedures } \\
\text { 3. Rules and Policies } \\
\text { 4. Performance Monitoring }\end{array}$ & $\begin{array}{l}\text { 1.Financial Reporting } \\
\text { (Disclosure) } \\
\text { 2. Non Financial } \\
\text { Reporting } \\
\text { 3. Performance } \\
\text { Evaluation }\end{array}$ \\
\hline
\end{tabular}

Corporate Governance Principles - TARIF

Corporate Governance Based:

Law(External/Internal)

Law Enforcement

Sumber: Majalah Usahawan edisi Juni (2003). 
Gambar 2.2

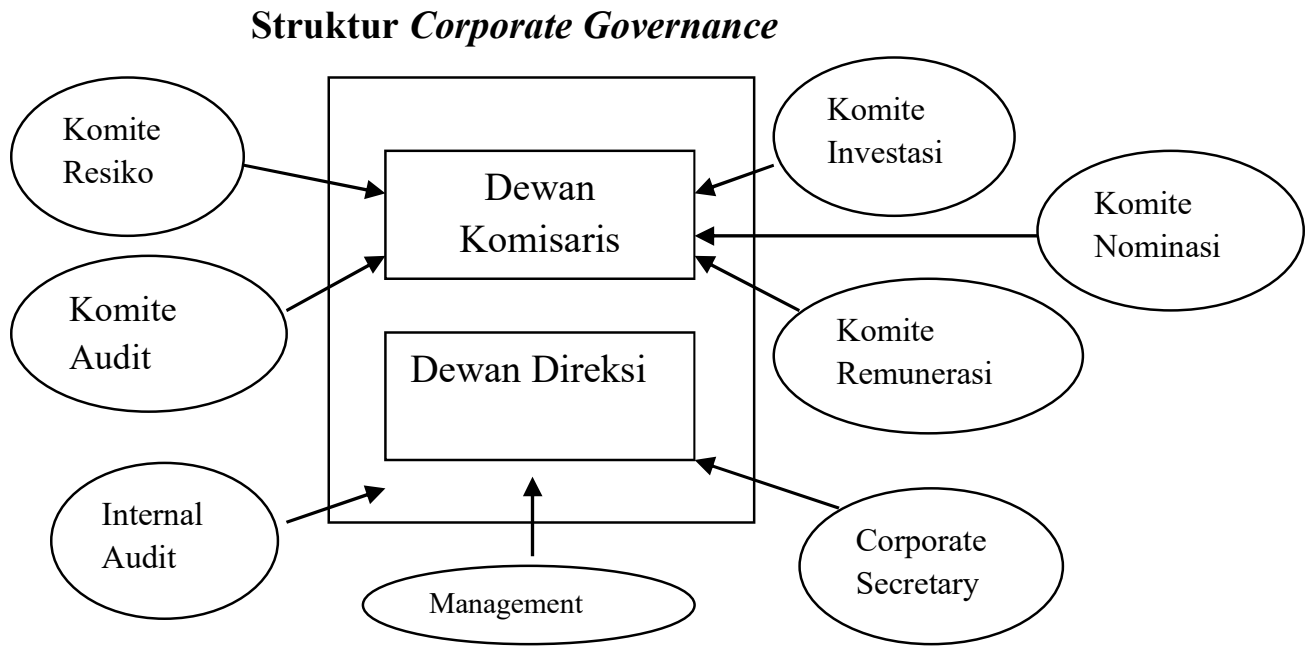

Sumber: Majalah Usahawan edisi Juni (2003)

\subsection{Set Kesempatan Investasi (IOS)}

Investasi merupakan salah satu indikator penting dalam meningkatkan nilai perusahaan. Pertumbuhan perusahaan diwujudkan dengan penggunaan dana untuk kebutuhan investasi. Semakin tinggi investasi yang dilakukan pada aset menunjukkan semakin tinggi pula tingkat pertumbuhan perusahaan. Menurut Myers (1977) dalam Oktarya et al (2013) IOS (Investment opportunity set) merupakan kombinasi antara aset yang dimiliki (asset in place) dengan pilihan investasi di masa mendatang dan juga sebagai kesempatan perusahaan untuk tumbuh.IOSdigunakan sebagai dasar untuk menentukan klasifikasi pertumbuhan di masa depan.Invesment opportunity set (IOS) merupakan sesuatu yang secara melekat bersifat tidak observasi. Karena sifatnya tidak dapat diobservasi, maka IOS memerlukan sebuah proksi (Hartono, 1999 dalam Kartina dan Nikmah, (2011). Salah satu proksi IOS berbasis harga yaitu proksi rasio perbandingan antara nilai buku aset perusahaan dengan nilai perusahaan dengan nilai pasar asset perusahaan tersebut atau sering disebut rasio market value tobook value of asset ratio (MVA/BVA). Menurut Kole 
(1991) dalam Novianti (2012), nilai IOS bergantung pada pengeluaran pengeluaran yang ditetapkan manajemen di masa yang akan datang (future discretionary expenditure) yang pada saat ini merupakan pilihan-pilihan investasi yang diharapkan akan menghasilkan return yang lebih besar dari biaya modal (cost of equity) dan dapat menghasilkan keuntungan. Tindakan manajer menjadi unobservable yang dapat menyebabkan prinsipal tidak dapat mengetahui apakah manajer telah melakukan tindakan yang sesuai dengan keinginan prinsipal atau tidak. Investment Opportunity Set (IOS) dari suatu perusahaan juga dapat mempengaruhi cara pandang manajer, pemilik, investor dan kreditor terhadap perusahaan. Perusahaan yang mempunyai kesempatan tumbuh yang tinggi dianggap dapat menghasilkan return yang tinggi pula dan akan mempengaruhi perubahan tingkatlaba dan menentukan kualitas informasi laba.

\subsection{Kualitas Laba}

$\begin{array}{ll}\text { Menurut } & \text { Surifah (2010)definisi } \\ \text { kualitas } & \text { laba adalah sebagai }\end{array}$

$\begin{array}{llr}\text { kemampuan } & \text { laba } & \text { dalam } \\ \text { merefleksikan } & \text { kebenaran } & \text { laba } \\ \text { perusahaan } & \text { dan } & \text { membantu } \\ \text { memprediksi } & \text { laba } & \text { mendatang, }\end{array}$
dengan mempertimbangkan stabilitas dan persistensi laba.Menurut Scott (2000) dalam Siregar dan Utama (2005) pengelolaan laba (earnings management) yang dilakukan perusahaan dapat bersifat efisien atau meningkatkan keinformatifan laba dalam mengkomunikasikan informasi private dan dapat bersifat oportunis atau manajemen melaporkan laba secara oportunis untuk memaksimumkan kepentingan pribadinya. Apabila pengelolaan laba bersifat oportunis maka kualitas informasi laba yang tersaji menjadi berkurang sehingga dapat berdampak bagi pengambilan keputusan investasi yang salah bagi investor. Menurut Balsam et al. (2003) dalam Abdelghany (2015)menyatakan bahwa tingkat dari discretionary accrual merupakan pengukuran langsung terhadap kualitas laba.

\subsection{Perumusan Hipotesis}

\subsubsection{Pengaruh Dewan Komisaris} Terhadap Kualitas Laba 
Menurut UU PT No.40 Tahun 2007 dewan komisaris adalah organ perusahan yang bertugas dan bertanggung jawab secara kolektif untuk melakukan pengawasan dan memberikan nasihat kepada direksi. Kepengurusan perseroan terbatas di Indonesia menganut two-board/tier system yaitu dewan komisaris dan direksi yang memiliki wewenang dan tanggung jawab yang jelas dengan fungsinya masing - masing sebagaimana yang telah diatur dalam anggaran dasar perusahaan dan peraturan perundang-undangan (fiduciary responsibility). Akan tetapi, dewan komisaris tidak boleh turut serta dalam pengambilan keputusan operasional. Oleh karena dewan komisaris tidak turut serta dalam pengambilan keputusan operasional, maka diharapkan dewan komisaris akan lebih objektif dalam memberikan penilaian terhadap kinerja perusahaan yang tercermin dalam laporan keuangannya. Dengan adanya dewan komisaris yang di dalamnya sekarang terdapat juga komisaris, maka diharapkan laporan keuangan yang tercipta memiliki kualitas laba yang tinggi. Tidak ada aturan yang membatasi jumlah dewan komisaris. Ada yang berpendapat bahwa jumlah dewan komisaris yang sedikit akan mampu bekerja lebih efektif karena tidak terlalu banyak suara dalam berdiskusi untuk mencapai kata mufakat. Akan tetapi ada yang berpendapat jumlah yang banyak adalah efektif karena akan mendapatkan banyak inputan dari berbagai sudut pandang pemikiran. Dari uraian diatas, maka dikembangkan hipotesis alternatif pertama yaitu :

\section{Ha 1 Dewan Komisaris memiliki pengaruh signifikan terhadap kualitas laba}

\subsubsection{Pengaruh Kepemilikan Institusional Terhadap Kualitas Laba}

Kepemilikan institusional merupakan kepemilikan saham yang dimiliki oleh pemerintah, perusahaan asuransi, investor luar negeri atau bank. Menurut Hashim \& Devi (2008) dalam Yushita (2013) menyebutkan bahwa dengan semakin besarnya peranan corporate governance dalam perusahaan maka peran dari investor institusional akan menjadi sangat penting. Hal ini 
terkait dengan peran investor institusional dalam melakukan pengawasan terhadap kinerja perusahaan, mencegah terjadinya konflik kepentingan dari pemegang saham minoritas perusahaan. Semakin besar kepemilikan oleh institusional maka akan semakin besar peran kepemilikan institusional tersebut dalam mekanisme Corporate Governance sehingga aspek pengawasan terhadap kinerja perusahaan akan semakin meningkat. Peningkatan aspek pengawasan melalui kepemilikan institusional akan mendorong manajemen untuk meningkatkan kinerja perusahaan dan mengurangi tindakan manajemen laba sehingga laporan laba yang dihasilkan berkualitas. Boediono (2005) dalam Kartina dan Nikmah (2011) menunjukkan bahwa kepemilikan institusional berpengaruh positifterhadap kualitas laba perusahaan. Semakin besar tingkat pengawasan yang dilakukan investor institusional, maka berdampak positif pada kualitas laba perusahaan tersebut

Dari uraian diatas, maka dikembangkan hipotesis alternatif kedua sebagai berikut:

\section{Ha2 : Kepemilikan Institusional memiliki pengaruh signifikan terhadap kualitas laba}

\subsubsection{Pengaruh Set Kesempatan Investasi (IOS) Terhadap Kualitas Laba}

Menurut penelitian Wah (2002) dalam Kartina dan Nikmah (2011) nilai IOS yang lebih tinggi menunjukkan adanya discretionaryaccrualsyang tinggi pula, namun apabila mereka memiliki auditor dari KAP Big 4 maka discreationary accrual akan menurun. Hasil tersebut mengindikasikan bahwa manajer dari perusahaan yang mempunyai peluang investasi yang tinggi, cenderung untuk memanipulasi discretionary accrual, yang dapat menyebabkan menurunnya kualitas laba perusahaan. Namun, kecenderungan ini akan hilang jika perusahaan telah menerapkan tata kelola yang baik dan mempunyai pengawasan audit yang lebih baik di lingkup perusahaan tersebut. Penelitian yang dilakukan Novianti (2012) dan Oktarya et al (2013) menunjukkan bahwa set kesempatan 
investasi (IOS) memiliki pengaruh signifikan terhadap kualitas laba. Semakin tinggi nilai set kesempatan investasi (IOS) perusahaan yang diproksikan dengan market to book value of asset (MVA/BVA) maka akan menyajikan informasi laba yang berkualitas. Atas dasar uraian diatas maka dikembangkan hipotesis alternatif ke-3 yaitu :

\section{Ha3 : Set Kesempatan Investasi (IOS) memiliki pengaruh signifikan terhadap kualitas laba}

\subsubsection{Pengaruh Ukuran \\ PerusahaanTerhadap \\ Kualitas Laba}

Perusahaan dengan ukuran yang lebih besar memiliki modal lebih besar, jumlah karyawan yang lebih banyak, penjualan lebih besar sehingga perusahaan relatif lebih stabil dan lebih mampu menghasilkan laba dibandingkan perusahaan berukuran kecil (Diantimala (2008) dalam Widayanti (2014)). Perusahaan yang lebih besar juga cenderung memperlihatkan kinerja yang lebih baik, karena mereka tentunya ingin agar para investor yang sudah menanamkan modal di tempatnya tidak dikecewakan dan berharap dengan kinerja yang lebih baik dapat menarik perhatian para calon investor lainnya. Dengan kualitas kinerja sesungguhnya yang lebih baik, tentunya menghasilkan kualitas laba yang tinggi. Perusahaan dengan ukuran yang lebih besar umumnya memiliki inisiatif untuk mengungkapkan lebih banyak informasi bila dibandingkan dengan perusahaan yang ukurannya lebih kecil untuk mendapatkan legitimasi dari stakeholders, karena bagaimanapun kelangsungan hidup perusahaan tergantung pada harmonisnya hubungan dengan stakeholders (Arfan dan Antasari, 2008) dalam Widayanti (2014). Atas uraian diatas maka dikembangkan hipotesis alternatif ke-4

\section{Ha4 : Ukuran Perusahaan memiliki pengaruh signifikan terhadap kualitas laba}

\section{METODE PENELITIAN}

\subsection{Data \& Sampel}

Data yang digunakan penelitian ini adalah data sekunder yaitu laporan keuangan tahunan atas perusahaan - perusahaan yang masuk ke dalam 
index LQ45 yang diperoleh dari www.idx.co.id. Adapun metode pengambilan sampel menggunakan purposive samplingdan terpililah sampel penelitiansebanyak 15 (lima belas) perusahaan yang masuk ke dalam index LQ45 periode 20122015 secara berturut-turut.

\subsection{Pengukuran Operasional}

Variabel

Berikut ini adalah tabel yang menyajikan data operasional variabel beserta dengan pengukurannya :

Tabel 3.1

Pengukuran Operasional Variabel

\begin{tabular}{|c|c|c|}
\hline Variabel & Definisi Operasional & Pengukuran \\
\hline $\begin{array}{l}\text { Ukuran } \\
\text { Dewan } \\
\text { Komisaris } \\
\text { (DK) }\end{array}$ & $\begin{array}{l}\text { Dewan komisaris adalah organ } \\
\text { perusahan yang bertugas dan } \\
\text { bertanggung jawab secara } \\
\text { kolektif untuk melakukan } \\
\text { pengawasan dan memberikan } \\
\text { nasihat kepada direksi (UU.No } \\
\text { 40 Tahun 2007) }\end{array}$ & $\begin{array}{l}\text { Dewan Komisaris (DK) : Jumlah seluruh } \\
\text { jajaran dewan komisaris di suatu perusahaan }\end{array}$ \\
\hline $\begin{array}{l}\text { Kepemilikan } \\
\text { Institusional } \\
\text { (KEP_INS) }\end{array}$ & $\begin{array}{l}\text { Kepemilikan institusional } \\
\text { merupakan kepemilikan saham } \\
\text { yang dimiliki oleh pemerintah, } \\
\text { perusahaan asuransi, investor } \\
\text { luar negeri atau bank. } \\
\text { Kepemilikan institusionaldiukur } \\
\text { dengan jumlah kepemilikan } \\
\text { saham oleh investor institusi } \\
\text { terhadap total jumlah saham } \\
\text { perusahaan yang beredar. } \\
\text { (Kartina dan Nikmah, 2011) }\end{array}$ & $\begin{array}{c}\text { KEP INS }= \\
\frac{\sum \text { saham yang dimiliki investor institusi }}{\sum \text { saham yang beredar }}\end{array}$ \\
\hline
\end{tabular}




\begin{tabular}{|c|c|c|}
\hline \multirow[t]{2}{*}{$\begin{array}{l}\text { Set } \\
\text { Kesempatan } \\
\text { Investasi } \\
\text { (IOS) }\end{array}$} & \multirow{2}{*}{$\begin{array}{l}\text { Diukur dengan menggunakan } \\
\text { proksi MVA/BVA dimana nilai } \\
\text { buku total aset dikurangi dengan } \\
\text { nilai buku total ekuitas, } \\
\text { ditambah dengan hasil } \\
\text { perkalianantara jumlah lembar } \\
\text { saham beredar dengan harga } \\
\text { penutupan sahamterhadap total } \\
\text { aset perusahaan (Yusuf dan } \\
\text { Firdaus, 2005 dalam Kartina dan } \\
\text { Nikmah, 2011). }\end{array}$} & Total Aset - Total Ekuitas $+\left(\sum\right.$ saham yan \\
\hline & & $\begin{array}{c}\text { Total Aset } \\
\end{array}$ \\
\hline \multirow[t]{2}{*}{$\begin{array}{l}\text { Kualitas Laba } \\
(E Q)\end{array}$} & $\begin{array}{l}\text { Kualitas laba dapat diukur } \\
\text { dengan rasio dari arus kas } \\
\text { operasi dibagi dengan laba } \\
\text { bersih. Semakin rendah nilai } \\
\text { dari rasio ini menunjukkan } \\
\text { semakin tinggi kualitas laba } \\
\text { yang dihasilkan. }\end{array}$ & $\begin{array}{l}\text { dimana : } \\
\mathrm{EQ}=\text { Earnings Quality } \\
\mathrm{CFO}=\text { Arus kas operasi perusahaan }\end{array}$ \\
\hline & $\begin{array}{l}\text { (Menurut Penman, } 2001 \text { dalam } \\
\text { Abdelghany, 2005) }\end{array}$ & $\mathrm{NI}=$ Laba bersih perusahaan \\
\hline
\end{tabular}

\subsection{Analisis Data}

Analisis data dalam penelitian ini dilakukan dengan statistik deskriptif, uji asumsi klasik dan pengujian hipotesis dengan bantuan program SPSS Statistics 22. Pengujian hipotesis dilakukan dengan menggunakan analisis linear berganda dengan tingkat signifikansi $\alpha=5 \%$. Sebagai persyaratan pengujian regresi berganda dilakukan uji asumsi klasik untuk memastikan bahwa data penelitian valid, tidak bias, konsisten, dan penaksiran koefisien regresinya efisien. Uji asumsi klasik meliputi uji normalitas,

uji multikolinearitas, uji

heterokedastisitas, dan uji autokorelasi.

\section{Hasil Penelitian Dan}

\section{Pembahasan}

\subsection{Hasil Pengujian Asumsi}

Klasik

Berdasarkan hasil pengujian dengan menggunakan SPSS 22, maka dapat dikatakan bahwa penelitian ini telah memenuhi uji asumsi klasik dengan hasil ringkasan hasil uji dapat dilihat pada tabel 4.1 (lihat lampiran) 


\subsection{Statistik Deskriptif}

Berikut ini adalah tabel yang menunjukkan hasil statistik deskriptif

Tabel 4.2

Statistik Deskriptif

\begin{tabular}{|c|c|c|c|c|}
\hline & $\mathrm{N}$ & Minimum & Maximum & Mean \\
\hline DK & 60 & 3.00 & 11.00 & 6.4667 \\
\hline KEP_INS & 60 & .18 & .81 & .5640 \\
\hline IOS & 60 & 1.01 & 7.11 & 2.2646 \\
\hline TA & 60 & 15.84 & 20.20 & 17.5129 \\
\hline EARN_Q & 60 & -2.65 & 4.31 & 1.1202 \\
\hline Valid N (listwise) & 60 & & & \\
\hline
\end{tabular}

Sumber:Hasil olahan data dengan SPSS

Dari tabel statistik deskriptif diatas dapat dilihat bahwa rata - rata jumlah anggota dewan komisaris adalah 6-7 orang, jumlah ini dapat dikategorikan berukuran sedang sedangkan rata-rata dari kepemilikan institusionalnya adalah sebesar $56,40 \%$. Nilai rata - rata dari set kesempatan investasi (IOS) adalah 2.27 sedangkan total aset 17.51. Nilai rata - rata dari kualitas laba sebesar 1.12, dimana nilai ini lebih besar dari satu sehingga dapat dikatakan bahwa nilai rata-rata kualitas laba di perusahaan sampel cenderung rendah, karena nilai arus kas operasi perusahaan (cash basis) lebih tinggi dibandingkan laba bersihnya (accrual basis) yang menandakan adanya kecenderungan discretionary accrual yang tinggi yang dapat mengarah kepada kualitas laba yang rendah.

\subsection{Hasil Pengujian Hipotesis (Uji t)}

Berikut ini adalah tabel yang memperlihatkan hasil uji parsial (ttest). 
Tabel 4.3 :

Hasil Uji-t

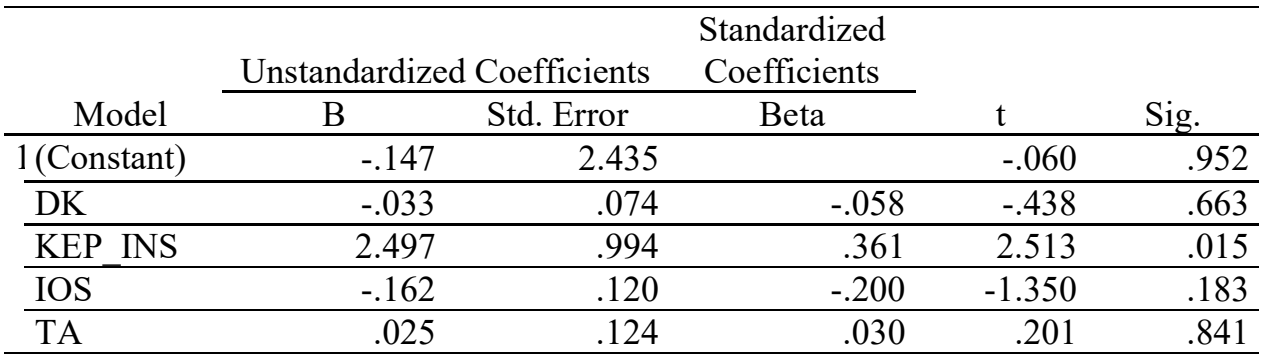

Sumber : Hasil olahan data SPSS 22

Analisa Pengaruh Dewan

\section{Komisaris terhadap Kualitas Laba}

Pengujian hipotesis mengenai pengaruh dewan komisaris terhadap kualitas laba menunjukkan arah negatif dengan nilai signifikansi sebesar 0,663yang berarti lebih besar dari $\alpha=0,05$. Hal ini menunjukkan bahwa dewan komisaris yang diproksikan dengan jumlah dewan komisaris tidak mempunyai pengaruh yang signifikan terhadap kualitas laba.Dengan demikian hipotesis Ha1 ditolak. Secara teori seharusnya keberadaan dewan komisaris mampu memberikan pengaruh dalam meningkatkan kualitas laba, namun berdasarkan pengujian atas sampel yang ada tidak memiliki pengaruh signifikan. Hal ini mungkin disebabkan proses pemilihan dewan komisaris yang tidak sesuai fit \& proper test yang sebenarnya. Masih perlu dikaji kembali apakah pemilihan para dewan komisaris ini benar - benar dilakukan dengan semestinya. Yang paling dikuatirkan adalah keberadaan dewan komisaris hanya untuk memenuhi aturan yang berlaku saja. Seyogyanya jika semua proses mulai dari pemilihan, kinerja, remunerasi dilakukan dengan baik dan benar, seharusnya akan memberikan pengaruh yang signifikan bagi terciptanya kualitas laba yang tinggi. Dari hasil uji hipotesis, juga terlihat bahwa arah yang dihasilkan adalah negatif artinya semakin banyak jumlah dewan komisaris justru kualitas labanya semakin turun. Hal ini mungkin disebabkan jumlah 
dewan komisaris yang banyak tidak disertai dengan efektivitas dalam bekerja. Sebenarnya mengenai jumlah dewan komisaris sangatlah tergantung dari kebutuhan suatu perusahaan akan fungsi yang hendak dijalankan dari para dewan komisaris tersebut.

Analisa Pengaruh Kepemilikan Institusional terhadap Kualitas Laba

Pengujian hipotesis mengenai pengaruh kepemilikan institusional terhadap kualitas laba menunjukkan arah positif dengan nilai signifikansi sebesar 0,015yang berarti lebih kecil dari $\alpha=0,05$. Hal ini menunjukkan bahwa kepemilikan institusional mempunyai pengaruh yang signifikan terhadap kualitas laba.Dengan demikian hipotesis Hazditerima. Hasil penelitian ini mendukung landasan teori yang mengatakan bahwa dengan semakin besar proporsi kepemilikan saham institusi di suatu perusahaan, maka tingkat pengawasan terhadap kinerja perusahaan jauh lebih tinggi, dibandingkan hanya dimiliki oleh masyarakat saja. Oleh karena umumnya dana yang disetor oleh pihak institusi lebih banyak dibandingkan masyarakat biasa, maka perusahaan akan berhati - hati terhadap pengawasan dari pihak institusi. Karena jika pihak institusi ini melihat kinerja manajemen tidak baik, maka pihak institusi dapat menarik dananya yang cukup besar itu, dan hal ini tentunya berusaha dihindari oleh perusahaan.

\section{Analisa Pengaruh Set Kesempatan} Investasi (IOS) terhadap Kualitas

\section{Laba}

Pengujian hipotesis mengenai pengaruh set kesempatan investasi (IOS) terhadap kualitas laba menunjukkan arah negatif dengan nilai signifikansi sebesar 0,183yang berarti lebih besar dari $\alpha=0,05$. Hal ini menunjukkan bahwa set kesempatan investasi tidak mempunyai pengaruh yang signifikan terhadap kualitas laba. Dengan demikian hipotesis $\mathrm{Ha}_{3}$ ditolak. Hal ini menunjukkan bahwa meskipun perusahaan memiliki peluang kesempatan investasi yang dapat membuka celah lebih besar bagi permainan akrual, akan tetapi perusahaan kemungkinan justru enggan melakukannya karena pada kondisi seperti ini perusahaan justru 
mengalami sorotan yang tajam dari berbagai pihak terutama investor karena dana para investor tertanam di dalam investasi tersebut. Justru pada saat - saat seperti ini perusahaan harus dapat membuktikan bahwa kinerja perusahaan meningkat sehingga informasi laba yang berkualitas tinggi.

\section{Analisa Pengaruh Ukuran \\ Perusahaan terhadap Kualitas Laba}

Pengujian hipotesis mengenai pengaruh ukuran perusahaan terhadap kualitas laba menunjukkan arah positif dengan nilai signifikansi sebesar 0,841yang berarti lebih besar dari $\alpha=0,05$. Hal ini menunjukkan bahwa ukuran perusahaan tidak mempunyai pengaruh yang signifikan terhadap kualitas laba. Dengan demikian hipotesis $\mathrm{Ha}_{4}$ ditolak. Hal ini berarti besar kecilnya suatu perusahaan yang diukur dari total aset tidak dapat dijadikan dasar untuk memperkirakan bahwa laba yang dilaporkan berkualitas atau tidak. Hasil penelitian ini berbeda dengan penelitian yang dilakukan oleh Carcello et.al (2006) dalam Rupilu (2011) yaitu ukuran perusahaan berpengaruh signifikan terhadap manajemen laba. Hal ini disebabkan perusahaan yang berada dalam sampel penelitian ini yaitu perusahan LQ45 merupakan perusahaan - perusahaan yang memiliki rata - rata ukuran total aset besaraannya relatif sama sehingga tidak terjadi perbedaan yang signifikan dalam melihat pengaruhnya terhadap kualitas laba. Selain itu semua perusahaan yang terdaftar dalam Bursa Efek Indonesia harus mematuhi peraturan yang berlaku mengenai penyampaian laporan keuangan yang sesuai dengan standar akuntansi keuangan, tidak terkecuali apakah itu perusahaan besar maupun kecil.

\section{Simpulan}

Berdasarkan hasil uji statistik dengan tingkat signifikansi $5 \%$ diperoleh kesimpulan sebagai berikut :

1. Dewan Komisaris tidak memiliki pengaruh signifikan terhadap kualitas laba

2. Kepemilikan Institusional memiliki pengaruh signifikan terhadap kualitas laba 
3. Set Kesempatan Investasi (IOS) tidak memiliki pengaruh signifikan terhadap kualitas laba

4. Ukuran perusahaan tidak memiliki pengaruh signifikan terhadap kualitas laba

\section{Keterbatasan dan Saran Penelitian}

- Pengukuran kualitas laba yang digunakan dalam penelitian masih sederhana yaitu menggunakan pendekatan discretionary accrual. Sebaiknya di penelitian selanjutnya, dapat digunakan pengukuran kualitas laba lainnya dengan menggunakan pendekatan earning management: real activities manipulation.

- Diharapkan di penelitian selanjutnya dapat memilih sampel perusahaan perusahaan/industri yang memiliki kecenderungan melakukan manajemen laba yang sifatnya situasional yang disertai dengan periode pengamatan yang tepat dimana pada masa itu kecenderungan untuk melakukan manajemen laba sedang tinggi.

Menguji variabel - variabel lainnya yang berpengaruh terhadap kualitas laba, tidak hanya dari sisi pengukuran angka, tetapi juga dapat dari sisi sosial, lingkungan, hukum, etika dan moral dari suatu perusahaan, keberadaan proporsi wanita di level manajemen tingkat atas.

\section{Daftar Pustaka}

Abdelghany, K.E.M. 2005. Measuring the quality of earnings. Managerial Auditing Journal, 20, 1001-1015.

Daniri, Mas Achmad. 2014. Lead by GCG. Gagas Bisnis. Jakarta.

Kartina, Eti dan Nikmah. 2011. Pengaruh Corporate Governance, Invesment Opportunity Set(IOS) Terhadap Kualitas Laba dan Nilai Perusahaan. Jurnal Akuntansi Vol 1, p92-121.

Majalah Usahawan, No. 06 Juni 2003.

Novianti, Rizki. 2012. Kajian Kualitas Laba pada Perusahaan Manufaktur yang terdaftar di Bursa Efek Indonesia. Accounting Analysis Journal.

Oktarya, Eka, Lili Syafitri dan Trisnadi Wijaya. 2013. Pengaruh Pertumbuhan Laba, Investment Opportunity Set, Leverage dan Ukuran Perusahaan Terhadap Kualitas Laba pada Perusahaan Manufaktur yang Terdaftar di BEI 
Rupilu, Wilsna. 2011. Pengaruh Mekanisme Corporate Governance terhadap Kualitas Laba dan Nilai Perusahaan pada Perusahaan Manufaktur yang Terdaftar di Bursa Efek Indonesia. Jurnal Akuntansi, Manajemen Bisnis dan Sektor Publik, Volume 8 Nomor 1, Oktober 2011, pp.101-127.

Siregar, Sylvia Veronica dan Siddharta Utama . 2005. Pengaruh Struktur Kepemilikan, Ukuran Perusahaan, dan Praktek Corporate Governance terhadap Pengelolaan Laba, SNA, Volume 8.

Surifah. 2010. Kualitas Laba dan Pengukurannya. Jurnal Ekonomi, Manajemen \& Akuntansi, Vol. 8, No. 2, Mei Agustus, p31-47.

Widayanti, at al. 2014. Faktor Faktor yang Mempengaruhi Kualitas Laba Pada Perusahaan
High Profile yang Terdaftar di BEI. Jurnal Dinamika Ekonomi \& Bisnis. Vol 11 No.1.

Widjaja, Fendi Permana dan Rovila El Maghviroh. 2011. Analisis Perbedaan Kualitas Laba dan Nilai Perusahaan Sebelum dan Sesudah Adanya Komite pada Bank-bank Go Public di Indonesia. Volume 1 Nomor 2, Juli 2011, pp 117 - 134 .

Yushita, Amanita Novi, Rahmawati dan Hanung Triatmoko. 2013. Pengaruh Mekanisme Corporate Governance, Kualitas Auditor Eksternal, dan Likuiditas terhadap Kualitas Laba. Jurnal Economia, Volume 9 Nomor 2.

UU PT No.40 Tahun 2007

www.swa.co.id

www.oecd.org

www.iicg.go.id

www.fcgi.or.id

www.idx.co.id 